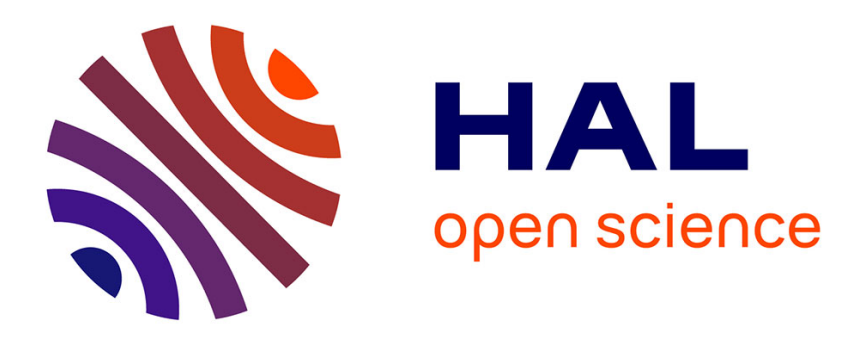

\title{
Using knowledge mapping to rethink the gap between science and action
}

Ruppert Vimal, Courtney Morgans

\section{To cite this version:}

Ruppert Vimal, Courtney Morgans. Using knowledge mapping to rethink the gap between science and action. Conservation Biology, 2020, pp.1 - 10. 10.1111/cobi.13563 . hal-02941455

\section{HAL Id: hal-02941455 \\ https://hal-univ-tlse2.archives-ouvertes.fr/hal-02941455}

Submitted on 17 Sep 2020

HAL is a multi-disciplinary open access archive for the deposit and dissemination of scientific research documents, whether they are published or not. The documents may come from teaching and research institutions in France or abroad, or from public or private research centers.
L'archive ouverte pluridisciplinaire HAL, est destinée au dépôt et à la diffusion de documents scientifiques de niveau recherche, publiés ou non, émanant des établissements d'enseignement et de recherche français ou étrangers, des laboratoires publics ou privés. 


\title{
Using knowledge mapping to rethink the gap between science and action
}

\author{
Ruppert Vimal (1) ${ }^{1,2}$ and Courtney Morgans ${ }^{3}$ \\ ${ }^{1}$ GEODE UMR 5602, CNRS, Université Jean-Jaurès, 5 Allée Antonio-Machado, Toulouse, 31058, France \\ ${ }^{2}$ German Centre for Integrative Biodiversity Research, Halle-Jena-Leipzig, Deutscher Platz 5e, Leipzig, 04103, Germany \\ ${ }^{3}$ Centre for Biodiversity and Conservation Science, School of Biological Sciences, The University of Queensland, Brisbane, QLD, \\ 4072, Australia
}

\begin{abstract}
Scholars have long stressed the need to bridge the gap between science and action and seek the most efficient use of knowledge for decision making. Many contributors have attempted to consider and understand the sociopolitical forces involved in knowledge generation and exchange. We argue, however, that a model is still needed to adequately conceptualize and frame the knowledge networks in which these processes are embedded. We devised a model for knowledge mapping as a prerequisite for knowledge management in the context of conservation. Using great ape conservation to frame our approach, we propose that knowledge mapping should be based on 2 key principles. First, each conservation network results from the conglomeration of subnetworks of expertise producing and using knowledge. Second, beyond the research-management gradient, other dimensions, such as the scale of operation, geographic location, and organizational characteristics, must also be considered. Assessing both knowledge production and trajectory across different dimensions of the network opens new space for investigating and reducing the gap between science and action.
\end{abstract}

Keywords: biodiversity, conservation network, knowledge management

Uso del Conocimiento del Mapeo para Replantear la Separación entre la Ciencia y la Acción

Resumen: Durante mucho tiempo los académicos han hecho énfasis en la necesidad de cerrar la brecha entre la ciencia y la acción, así como encontrar el uso más eficiente del conocimiento para la toma de decisiones. Muchos contribuyentes han intentado considerar y entender las fuerzas sociopolíticas involucradas en la generación e intercambio de conocimiento. Sin embargo, argumentamos que todavía se necesita un modelo para conceptualizar y enmarcar adecuadamente las redes de conocimiento en las que están incorporados estos procesos. Diseñamos un modelo para el mapeo del conocimiento como prerrequisito para el manejo del conocimiento como parte del contexto de la conservación. Usamos la conservación de los grandes simios para enmarcar nuestra estrategia y proponemos que el mapeo del conocimiento debería estar basado en dos principios clave. Primero, cada red de conservación es resultado de la conglomeración de subredes de experiencias que produce y usa conocimiento. Segundo, más allá del gradiente de manejo de investigaciones, otras dimensiones como la escala de operación, la ubicación geográfica y las características de organización también deben considerarse. La evaluación de la producción y la trayectoria del conocimiento a través de diferentes dimensiones de la red de conservación abre un nuevo espacio para la investigación y la reducción de la brecha entre la ciencia y la acción.

Palabras Clave: biodiversidad, manejo del conocimiento, red de conservación 


\begin{abstract}
摘要: 长期以来, 学者们一直强调应填补科学与行动之间的鸿沟, 并寻求在决策中最有效地利用知识。许多研究 者试图考虑和理解在知识产生和交流中涉及的社会政治力量。然而, 我们认为仍需要用模型来充分概念化并构 建嵌人这些过程的知识网络。我们设计了一个保护背景下的知识图谱模型, 以作为知识管理的前提条件。本研 究利用类人猿保护来构建相关方法, 并提出知识图谱应基于两个关键原则。第一, 每一个保护网络都是由生产 和使用知识的专业知识子网络聚集而成的。第二, 必须考虑除研究管理梯度之外的其它维度, 如保护行动的规 模、地理位置和组织特征。评估网络中不同维度的知识生产和知识轨迹, 将为研究和缩小科学与行动之间的差 距开辟新的空间。翻译: 胡怡思; 审校: 聂永刚
\end{abstract}

关键词: 知识管理, 生物多样性, 保护网络

\section{Introduction}

In recent decades, scientific knowledge has been the cornerstone of strategies to preserve Earth's biosphere (Balmford et al. 2005). However, despite massive investments in "knowing in order to conserve" (Vimal 2017), the environmental crisis has not been solved and biodiversity continues to decline (Butchart et al. 2010). In seeking the most efficient use of knowledge for action, scholars conceptualized the existence of a gap that should be bridged between producers and users of knowledge. Literature on this topic alternatively refers to the knowledge-action gap (Cook et al. 2013), knowingdoing gap (Hulme 2014), research-implementation gap (Knight et al. 2008; Arlettaz et al. 2010), sciencemanagement divide (Roux et al. 2006), gap between science and practice (Cabin 2011), and gap between research and practical management (Armstrong \& McCarthy 2007).

However, the way academics frame this gap and the solutions they conceive to narrow it rely on and reflect 2 major conceptions of the relationship between science and society (Toomey et al. 2017; Bertuol-Garcia et al. 2018). Ecologists and conservationists commonly adhere to a positivist approach and consider predominantly the gap between researchers as producers and practitioners as users of academic knowledge. Accordingly, they focus on knowledge transfer, which they consider the delivery and reception of information following a one-way process (Pregernig 2014). This conception has been widely criticized (e.g., Roux et al. 2006; van Kerkhoff \& Lebel 2006) because it is based on the assumption of a linear and unidirectional movement of scientific knowledge and fails to consider complex entanglements between knowledge production and decision making as well as between scientific knowledge and other sources of information.

In contrast, the emergence of environmental humanities, which considers the social issues related to humannature relationships (Sörlin 2012), paved the way to reframing the science-policy interface and, accordingly, to reconceptualizing the gap. From this perspective, science and technology studies provide key concepts to capture the relation between science and society and between knowledge production and decision making (Latour 1987; Porter 1996; Carolan 2006; Jasanoff 2012). Building on a constructivist approach, scholars in the field have particularly stressed the need to consider the production of scientific facts as socially and politically embedded. Rather than being static and independent from social realities, science relies on processes shaped across complex interactions within networks of various actors (Callon 1984; Latour 2005). This conception is particularly true for policy-driven sciences, such as conservation science (Meine et al. 2006), and calls for a broad and integrative perception of scientific knowledge, whereby expertise in policy implementation, management, and monitoring is of equal importance to research-oriented activity (Cook et al. 2013; Cvitanovic et al. 2016). Concepts, such as contextualized, postnormal, and regulatory science, capture this idea that knowledge production is not just an academic activity but may also be fully embedded in bureaucratic, administrative, and management contexts (Funtowicz \& Ravetz 1993; Gibbons 2000; Jasanoff 2009).

In opposition to the rationalist model of knowledge transfer from research to practice, such framing suggests new ways of knowledge management at the sciencepractice interface (Reed et al. 2013). Based on this perspective, scholars have stressed the need to understand the processes involved in the "sharing, generation, coproduction, co-management and brokerage" of knowledge (Fazey et al. 2013).

Over the last decade, a number of contributions have been made to foster knowledge exchange among stakeholders by considering the effect of power, cultural norms, trust, social interactions, and values in shaping the production and movement of knowledge (e.g., Hegger et al. 2012; Boswell \& Smith 2017; Knight et al. 2019; Scarano et al. 2019). Scholars alternatively refer to the research-implementation space (Toomey et al. 2017; Buschke et al. 2019), knowledge mediation sphere (Nguyen et al. 2017), knowledge system (Cash et al. 2003), and knowledge network (Phelps et al. 2012) in which such processes are involved and where knowledge should be managed.

In support of this approach, we argue that effective knowledge management additionally requires an 
understanding and a conceptualization of the knowledge network in itself. Environmental issues involve networks of various stakeholders (Reed 2008; Bodin \& Crona 2009), and a comprehensive model is still required to investigate the multiple sources and the flow of information within these networks. Literature on social network analysis in the context of environmental management has been increasingly fruitful over the last 2 decades (e.g., Prell et al. 2009; Guerrero et al. 2013; Wood et al. 2014). By investigating relationships between stakeholders, social-network analysis can provide insights, such as how frequently interactions between actors are taking place and for what purpose (Morgans et al. 2017; Guerrero et al. 2020). Conversely, knowledge mapping has been proposed as a process to survey knowledge and its connections in a system such that the mapping itself also creates additional knowledge (Vail III 1999; Wexler 2001). The aim of the map is, therefore, to make visible the expertise of a given organization, considered as the pool of knowledge and skills used to drive action and decision. Although environmentalists have identified knowledge mapping as key for knowledge management (Reed et al. 2009; Jetz et al. 2012; Pascual et al. 2016), a conceptual model is still required to adequately capture the complexity of the relationship between knowledge production and action.

We devised a model for knowledge mapping as a prerequisite for effective knowledge management in the context of conservation. We considered a conservation network as a conglomeration of different subnetworks of expertise in which knowledge is produced and used and examined the various dimensions across which knowledge production and trajectory can be assessed. Finally, we considered key issues in investigating the scienceaction gap and managing knowledge.

\section{A Model for Managing Knowledge in a Conservation Network}

Originally developed for and applied in business management, knowledge mapping was proposed as a technique to foster knowledge management in organizational contexts to increased innovation and performance (Liebowitz 2005). Overall, such mapping aims to mobilize, diffuse, and evaluate intellectual capital in a given organization (Wexler 2001). It is based on a "knowledge audit process" and helps identify needed skills and information, encourages reuse of ideas, prevents reinvention, highlights islands of expertise and emerging practices, and suggests bridges for sharing (Liebowitz et al. 2000). Different mapping techniques are used (Balaid et al. 2013), and it is widely accepted that organizations must decide what knowledge should be mapped and for which purpose (Jafari et al. 2009). The map can, for instance, reveal who holds what type of knowledge, how it is stored and maintained, and what medias are used to disseminate and transfer it (Burnett et al. 2004).

We sought to adapt the concept of knowledge mapping in the field of conservation with the aim of bridging the gap between science and action. Our goal was thus to provide a model through which to map the production and trajectory of scientific knowledge across a given conservation network. Knowledge mapping here is understood as a conceptual approach aiming to garner knowledge across complex networks, rather than a method for visualizing different knowledge on a map. Thus, we did not aim to provide concrete methods of how to map knowledge; rather, we highlighted critical principles that can be applied to assessing knowledge in a conservation network and managing it accordingly. We hope that practitioners and academics can use our model to foster future experimentations with knowledge mapping in conservation. As an illustration, we show how the model can be applied to identify potential knowledge gaps and to manage knowledge in the context of great ape conservation.

We considered a conservation network, a network in which various expertise is mobilized to manage a given problem (Table 1). Our model can be applied to different case studies as diverse as, for instance, as conservation of a species worldwide, restoration of landscape corridors at a district level, management of fish stocks in a coastal region, and preservation of invertebrates in a context of intensive farming. Here, a conservation network can thus refer to a "knowledge network" as proposed by Phelps et al. (2012).

We believe the proposed model can be applied to different kinds of knowledge as far as they can be described. Following Raymond et al. (2010), this can include experiential, local, scientific, or hybrid knowledge. To simplify the demonstration and coherence of the illustrations used to build the model, we focused on scientific knowledge. Scientific knowledge refers to any information that emanates from scientific study and adheres to the criteria of reliability and validity. Considered explicit knowledge, it is generated through a formalized process and articulated in written or spoken form (Nonaka 1994). To illustrate our approach, we focused mainly on the spatial dimension of expertise within the great ape conservation network (Table 2). We made this choice because of our experience in this field and the recent publication of several articles related to spatial monitoring practices and knowledge exchange in great ape habitats (Morgans et al. 2017; Vimal 2017; Vimal et al. 2018a, 2018b). We used this material to frame our model and provide illustrative examples, rather than to properly map knowledge in the great ape conservation network. 
Table 1. Definitions of the terms used in the article.

\begin{tabular}{|c|c|}
\hline Terms & Definition \\
\hline Conservation network & $\begin{array}{l}\text { combination of interdependent subnetworks that produce and use knowledge in relation to one } \\
\text { conservation issue }\end{array}$ \\
\hline Subnetwork & $\begin{array}{l}\text { specific entity defined by different attributes across various dimensions and aiming to produce a } \\
\text { given knowledge }\end{array}$ \\
\hline Expertise & process mobilizing and producing a pool of knowledge at a subnetwork level \\
\hline Knowledge distribution & both knowledge production and knowledge trajectory \\
\hline Cluster & broad grouping of subnetworks based on shared attributes \\
\hline Dimension & means of classifying a subnetwork \\
\hline Attribute & characteristic of a subnetwork following a given dimension \\
\hline Headquarter & location of the leading organization \\
\hline Topic & topic of interest of the expert \\
\hline Operationality & degree of application of expertise \\
\hline
\end{tabular}

\section{Conceptualizing Knowledge within a Conservation Network}

A conservation network can be assessed as the conglomeration of various, fully interdependent subnetworks of expertise that aim to produce specific items of knowledge (Fig. 1a). Table 2 contains examples of such expertise related to great ape conservation in varying capacities. Our approach, therefore, values a large vision of science, whereby knowledge production does not only rely on academics but more generally on every organization involved in a scientific process (Enengel et al. 2012). Following this conceptualization, monitoring programs in national parks and International Union for Conservation of Nature species red-list assessment (Table 2), for instance, thus become part of the scientific activities implemented for great ape conservation.

In the process of creating new knowledge, each subnetwork of expertise relies on a pool of existing knowledge (Phelps et al. 2012). Consequently, knowledge can be the output of one subnetwork and the supporting information in some others. Each subnetwork involves both the use and the production of knowledge. For instance, the recent assessment of the impact of resource use and land-use changes on the density distribution of Bornean orangutans (Pongo pygmaeus) (Table 2) relied on existing remote-sensing and field-survey data, various information related to the ecology of the species, and spatial distribution models (Voigt et al. 2018). As outputs, this expertise produced new data on orangutan density based on which a causal relationship between the state of the population and the rate of logging, deforestation, and plantations has been found. Through this process, the authors improved the modeling technique used to address problem of sparse data on wildlife distribution.

Knowledge mapping should not be based on a dualist representation with knowledge producers on one side and knowledge users on the other side. Rather, we propose that each subnetwork produces and uses knowl- edge. Far from the consideration of a unidirectional transfer from one entity to the other, our approach, therefore, highlights two main issues in terms of knowledge mapping. First, knowledge can be assessed across the conservation network according to its production to determine what knowledge is produced in which subnetwork. Here, the distribution of knowledge is assessed independently of its destination. Second, knowledge can be assessed across the conservation network according to its movement to determine what knowledge is used in which subnetworks. We sought to identify connections between subnetworks. Because each subnetwork produces knowledge, the movement of information must be considered multidirectional.

Knowledge mapping usually focuses on assessing who holds which skills and knowledge in a given organization (Burnett et al. 2004). Designed to address the problem of the knowledge-action gap, our approach emphasizes processes and focuses on who generates knowledge, who mobilizes knowledge, and how knowledge flows.

\section{Assessing Knowledge Distribution Through Different Dimensions}

Although scholars are increasingly investigating the processes involved in what we here called a subnetwork of expertise (e.g., Tengö et al. 2017; Lacey et al. 2018; Buschke et al. 2019), an understanding of the multiple dimensions around which each subnetwork can be shaped and described is still needed. Indeed, it is increasingly recognized that knowledge exchange is more than a 1-dimensional interaction between academics and practitioners. Beyond the individual organization leading the expertise, knowledge distribution can be conceptualized across multiple additional dimensions, such as the scale of operation, geographic location of the study, focal topic, degree of operationality, and discipline mobilized (Fig. 1b). Several studies have shown how some of these dimensions can be crucial in investigating knowledge 


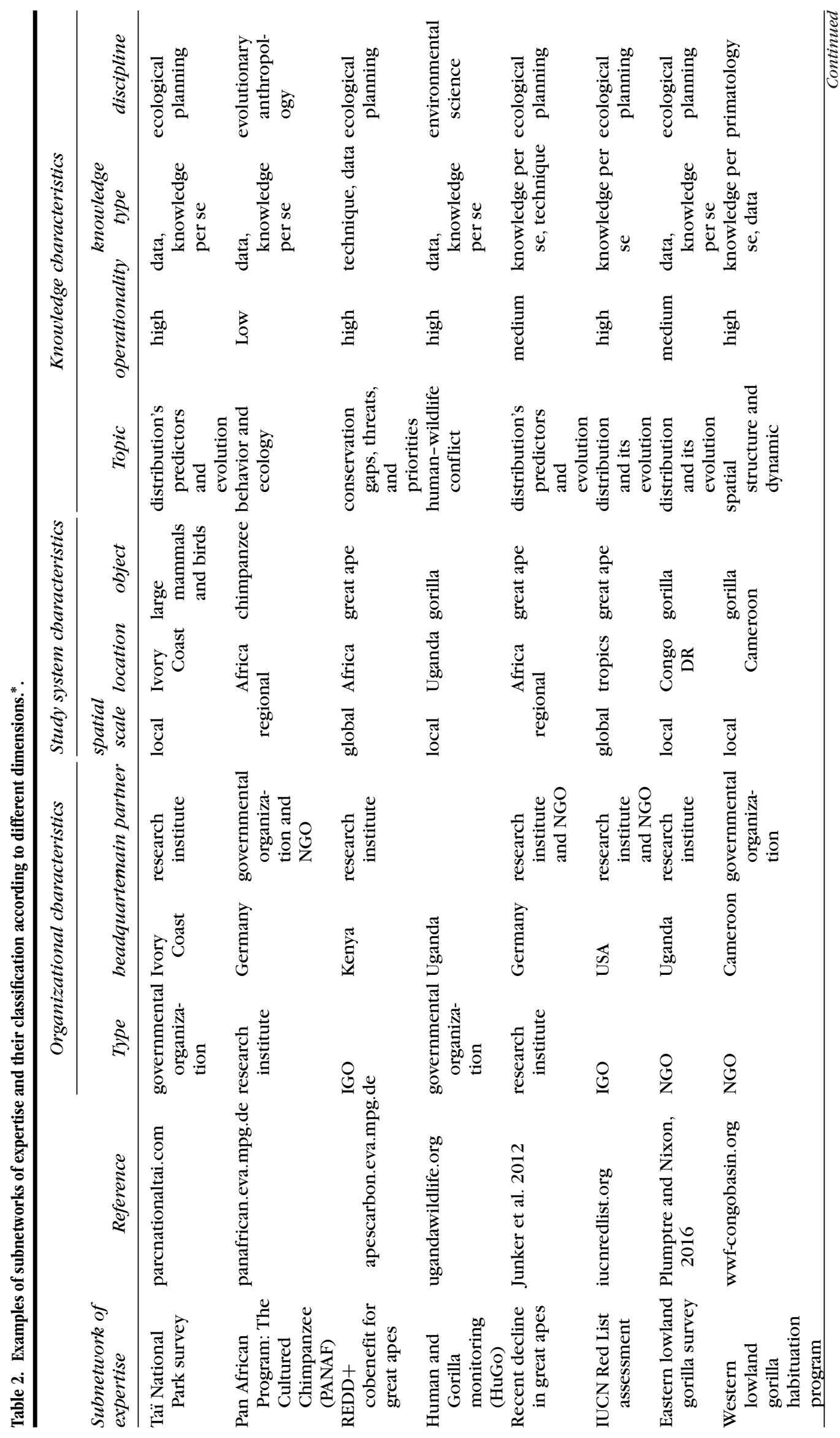




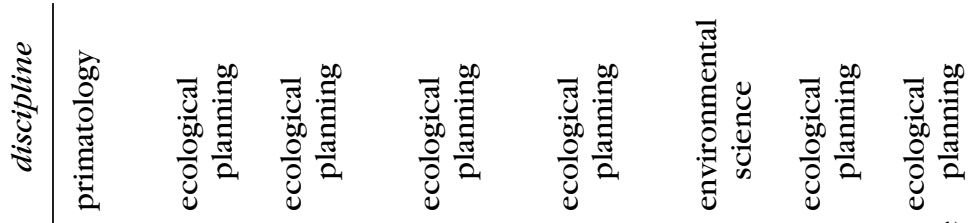

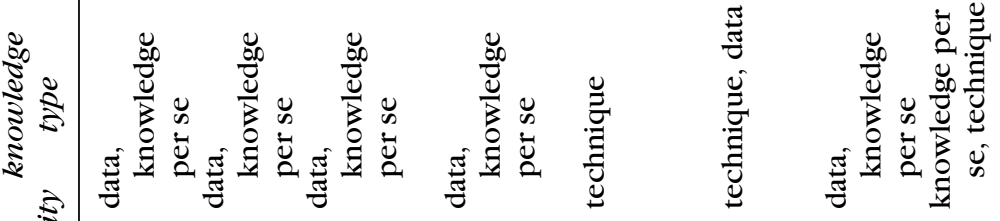

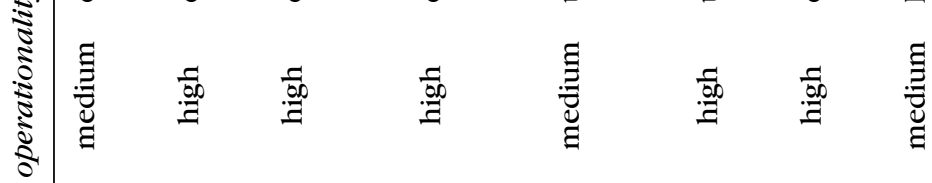

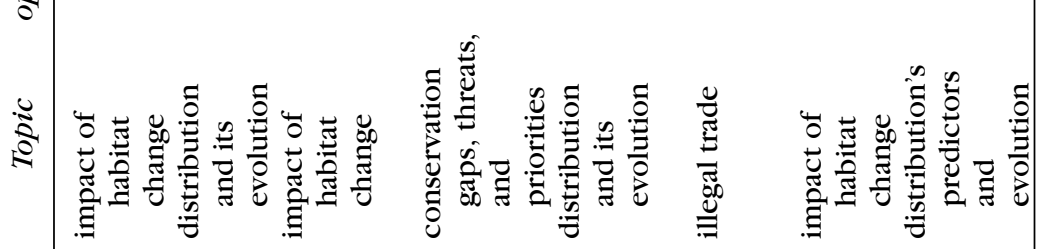

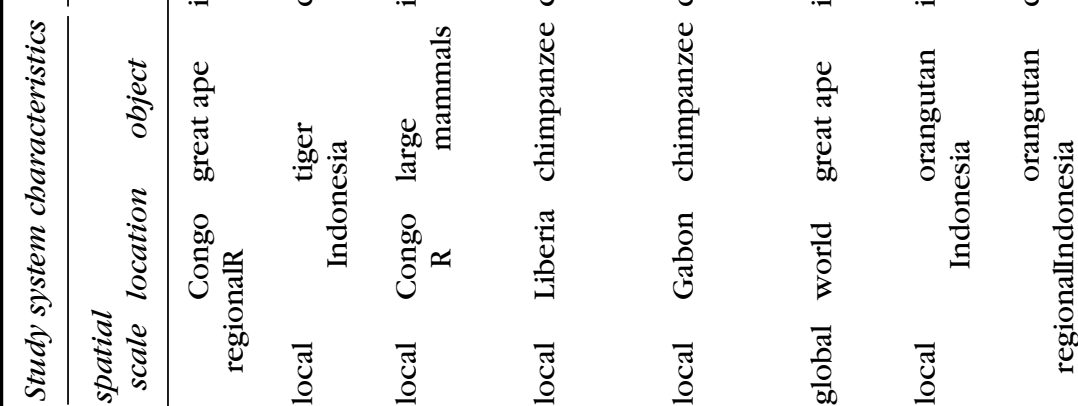

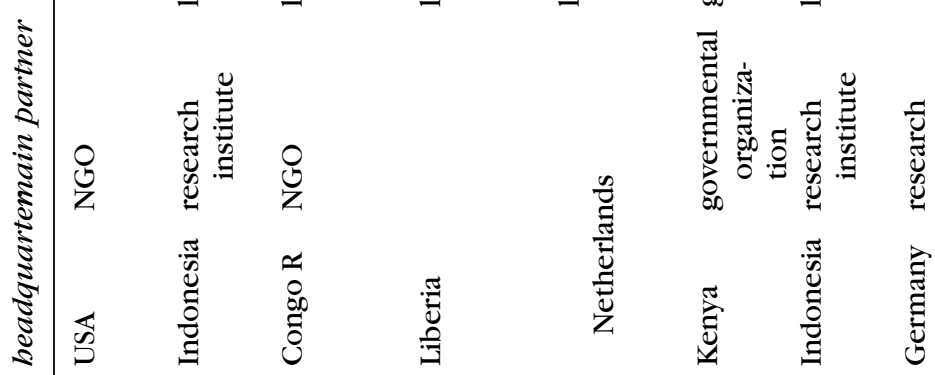

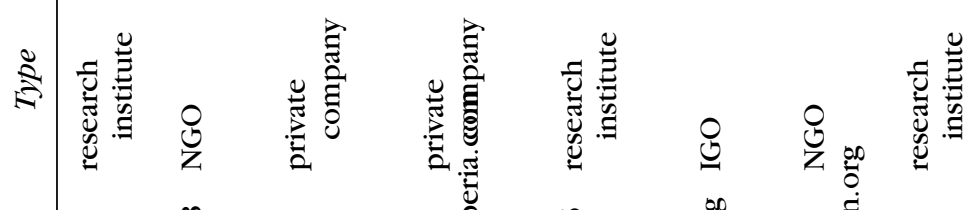

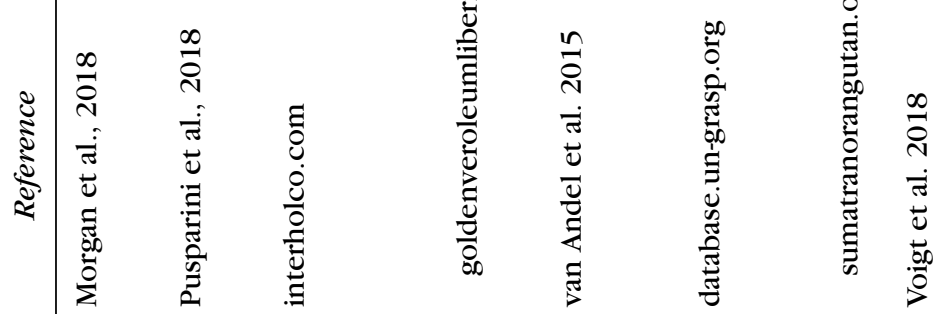

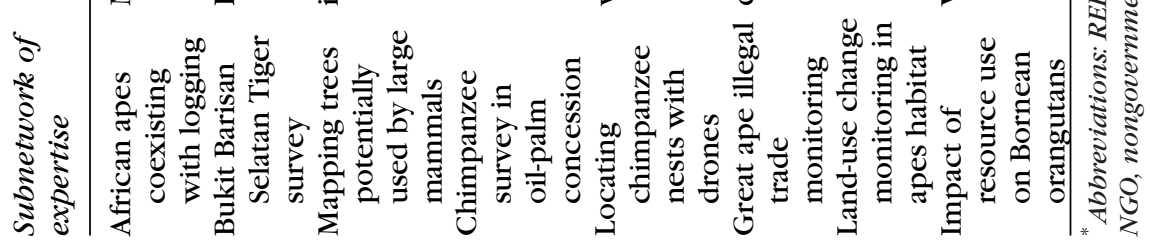


(a)

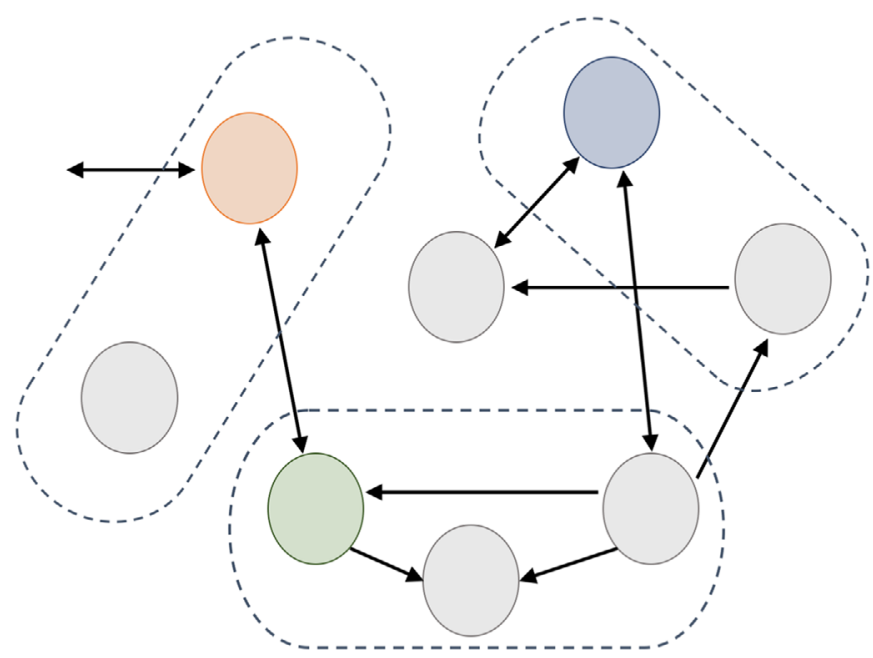

(b)

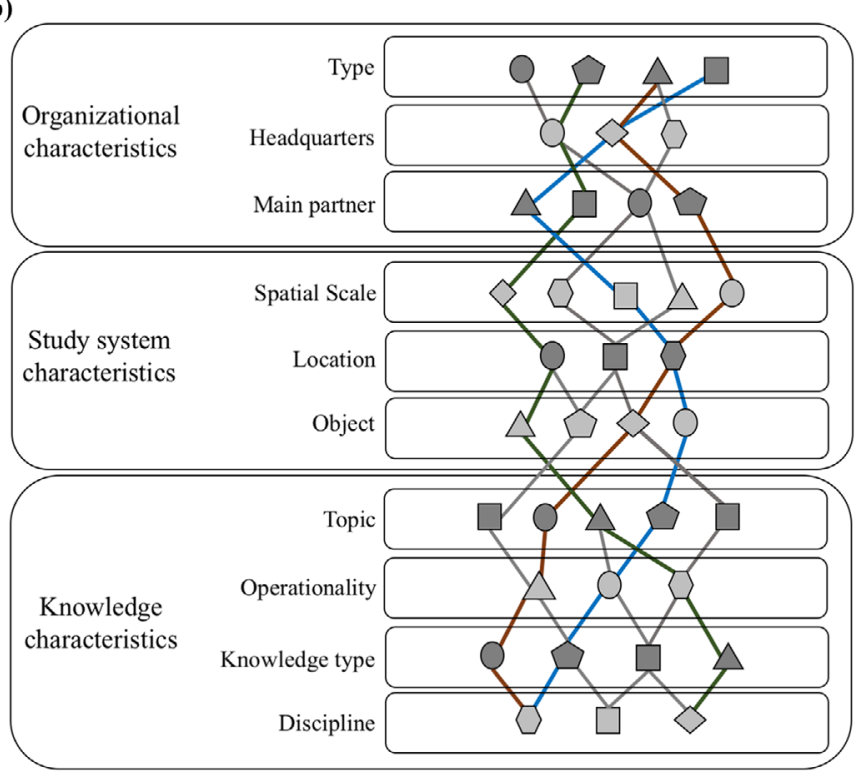

Figure 1. A conservation network of expertise represented as the conglomeration of different subnetworks: (a) knowledge trajectories (arrows) in the movement of knowledge from the subnetworks where it is produced to the subnetworks where it is used (each subnetwork is represented as a circle in [a] and as a line connecting different attributes in [b]; dashed lines, clusters of subnetworks that share similar attributes) and (b) various dimensions of subnetworks (different symbols represent different attributes across the various dimensions (not all circles of the lightest gray in [a] are represented in [b]).

distribution across networks (e.g., Stevens et al. 2007; Soberon \& Sarukhan 2009; Cook et al. 2013; Habel et al. 2013; Fleischman \& Briske 2016).

We proposed a set of the main dimensions to be considered when dealing with assessing knowledge distribution in a given conservation network. However, many other dimensions can be identified, such as social context (political system, degree of poverty, education level, etc.) and environmental conditions (ecoregions, elevation, climate, etc.) in which a given expertise is developed and implemented.

Although each subnetwork is unique, different subnetworks can be clustered according to the dimensions considered (Fig. 1a \& Table 2). For instance, despite their differences, the survey of eastern lowland gorillas (Gorilla beringei graueri), the habituation program of Campo Ma'an National Park, and the tiger survey in the Gunung Leuser all involve nongovernmental organizations (NGOs) (Table 2) and therefore can be considered as belonging to a single cluster (i.e., expertise run by NGOs) in the dimension type of organization. Clusters can also be defined based on several dimensions. For instance, the wildlife survey of the Tai National Park and the human and gorilla monitoring program in Uganda are both applied to direct management implemented at a local scale. They can, therefore, be considered as belonging to a single cluster (i.e., expertise run locally by governmental organizations with high degree of operationality) in the dimensions scale, type of organization, and operational- ity. Clusters thus offer rough classification of different subnetworks of expertise that can then be used to describe knowledge distribution.

Such an approach calls for consideration of a conservation network as open and without clear borders. Indeed, interdependencies can potentially reveal connections between seemingly distant subnetworks of expertise. For instance, the Pan-African program, which aims to provide fundamental knowledge on chimpanzees culture, can be considered related to the survey of chimpanzees in the high-conservation-value areas of Liberian oil-palm concessions. These subnetworks share the same study object (i.e., chimpanzee).

Considering the dimensions around which subnetworks or clusters of subnetworks can be described provides useful insights into how to assess knowledge distribution across a given conservation network. Knowledge mapping should not be based only on a one-dimensional representation of knowledge but rather on a multidimensional approach able to depict the complexity of the considered network.

\section{Toward Rethinking the Gap}

Over the last 2 decades, scholars mainly considered a single dimension of a conservation network in which knowledge movement was unidirectional and stressed 
the need to bridge the gap between researchers as producers and practitioners as users of knowledge. Alternatively, our model calls for a broader consideration of the gap based on 2 key principles that shape the way knowledge can be assessed across a given conservation network. First, a conservation network arises from the conglomeration of different subnetworks of expertise in which knowledge is produced and used. Second, each subnetwork of expertise can be described according to several dimensions. We thus argue that knowledge management should rely on an assessment of both knowledge production and trajectory across different dimensions of the network.

Beyond the usual question of how is knowledge produced by researchers being used by practitioners, multiple issues can, therefore, be investigated in relation to the distribution of knowledge in a given conservation network. The examples below illustrate different ways of assessing knowledge across the great ape conservation network and alternatively across the tropical national parks conservation network. Both production and trajectory can be questioned according to one or several dimensions.

\section{Assessing Knowledge Production}

What knowledge is produced on different chimpanzee subspecies (example 1, study object)? The chimpanzee range includes 4 subspecies with different behavior, protection status, and ecology. It is, therefore, crucial to assess whether knowledge production is balanced between these different subspecies. In this respect, the PanAfrican program, a research project investigating behavioral traits of poorly known populations across the entire chimpanzee range (Table 2), can be identified as key to filling potential gaps.

What knowledge is produced on different study objects and different degrees of operationality in tropical national parks (example 2, study object and operationality)? In a recent study (Vimal et al. 2018a), we assessed the nature and operationality of monitoring programs conducted across different national parks in Africa and Asia. Overall, we found that such programs focus much more on large mammals and following long-term protocols than on other taxonomic groups and short-term interventions.

These 2 examples illustrate the potential use of knowledge mapping in assessing knowledge production across various dimensions. Previously, researchers stressed the need to consider the heterogeneity of knowledge production in conservation sciences between disciplines (Bennett et al. 2017a, 2017b), between data quantity and quality (Bayraktarov et al. 2019), and between among topics (Di Marco et al. 2017). Example 1 shows how a subnetwork of expertise (a cluster of scientific activities implemented through the Pan African program) can play a key role in balancing knowledge production in one dimension (i.e., different chimpanzee subspecies). Example 2 demonstrates how knowledge production is not neutral but reveals preferences and perception according to various dimensions (i.e., a rather rationalist approach to nature conservation focused on a fragmented portion of ecosystems). Overall, beyond providing a critical view on scientific activities, assessing knowledge production can help support existing scientific activities or orient and prioritize future knowledge development and exchange.

\section{Assessing Knowledge Trajectory}

What is the trajectory of knowledge according to different scales and different organizations in the context of great ape conservation (example 3, scale and organization)? Data collected by the Tail National Park in the Ivory Coast to inform its law enforcement strategy were used by Junker et al. (2012) to assess the factors shaping the decline of great apes regionally (Table 2 ). Knowledge transfer was then operated from a subnetwork involving governmental institutions and NGOs at a local scale to a subnetwork involving a research institute at a regional scale.

What is the trajectory of knowledge according to different knowledge types and different organizations in tropical national parks (example 4, organization and knowledge type)? The Wildlife Conservation Society invested a large amount of money to develop the Spatial Monitoring and Reporting Tool (SMART smartconservationtools.org) and trained national park rangers to use the tool to produce data on law enforcement (Vimal et al. 2018a). The transfer of knowledge is operated from an international NGO providing tools and techniques to local managers for producing data.

In terms of knowledge trajectory, although the transfer of knowledge from research to management remains at the forefront, multidirectional movement of knowledge must also be considered across various dimensions. Examples 3 and 4 illustrate the potential of knowledge mapping as a way to assess knowledge flows across various dimensions. Example 3 shows how research activities, even if fundamental, heavily rely on knowledge produced by practitioners in the context of wildlife management. It reveals existing interdependencies across a given conservation network and the multidirectional flow between research and management. Example 4 provides useful insights into how specific kinds of knowledge associated with specific organization can structure and homogenize the way local practitioners produce knowledge for action. Mapping knowledge flows may thus help in understanding which collaborations are key to maintain, which ones may be questionable, and which ones should be developed further. 


\section{Conclusions}

Using a network perspective, our model suggests key considerations for knowledge mapping as a prerequisite of knowledge management in the context of conservation. The production and use of knowledge is not the result of a single, one-dimensional network; rather, it relies on a multitude of interdependent subnetworks. Over the last decades, many scholars have stressed the need to understand and manage the sociopolitical issues involved within and between these networks. Our primary message is that such approaches should be based on a diversity of representations depicting the complexity of a given conservation network and highlighting both a multitude of potential gaps and opportunities for further knowledge development and use.

Assessing both knowledge production and trajectory across the diverse dimensions of a conservation network opens new spaces for further investigating the gap and accordingly managing knowledge. It helps in adjusting, prioritizing, and optimizing investments of scarce resources in conservation science. Although our model provides insights into how to adapt the concept of knowledge mapping for environmental conservation, different approaches may be considered further. What makes up the map can, therefore, alternatively range from qualitative description to semiquantitative and quantitative indicators of knowledge distribution. Although knowledge maps can provide a diagrammatic representation, necessarily simplistic, of reality, care should be taken to avoid oversimplification. In particular, knowledge development follows a continuous process, whereby knowledge is constantly transformed while it is exchanged. Although it is meant to assess knowledge at a network scale and facilitate its management accordingly, our approach should not hinder understanding of complex processes involved in knowledge generation and movement or discount the existence of tacit and nonmappable knowledge.

\section{Acknowledgments}

This project was supported by the German Centre for Integrative Biodiversity (iDiv) and the Max Planck Institute for Evolutionary Anthropology. C.L.M. was supported by an Australian Research Training award.

\section{Literature Cited}

Arlettaz R, Schaub M, Fournier J, Reichlin TS, Sierro A, Watson JEM, Braunisch V. 2010. From publications to public actions: when conservation biologists bridge the gap between research and implementation. BioScience 60:835-842.

Armstrong DP, McCarthy MA. 2007. Big decisions and sparse data: adapting scientific publishing to the needs of practical conserva- tion. Avian Conservation and Ecology 2. http://www.ace-eco.org/ vol2/iss2/art14/.

Balaid A, Zibarzani M, Rozan MZA. 2013. A comprehensive review of knowledge mapping techniques. Journal of Information Systems Research and Innovation 3:61-66.

Balmford A, et al. 2005. The convention on biological diversity's 2010 target. Science 307:212-213.

Bayraktarov E, Ehmke G, O'Connor J, Burns EL, Nguyen HA, McRae L, Possingham HP, Lindenmayer DB. 2019. Do Big unstructured biodiversity data mean more knowledge? Frontiers in Ecology and Evolution 6. https://doi.org/10.3389/fevo.2018.00239.

Bennett NJ, et al. 2017a. Mainstreaming the social sciences in conservation. Conservation Biology 31:56-66.

Bennett NJ, et al. 2017b. Conservation social science: understanding and integrating human dimensions to improve conservation. Biological Conservation 205:93-108.

Bertuol-Garcia D, Morsello C, El-Hani CN, Pardini R. 2018. A conceptual framework for understanding the perspectives on the causes of the science-practice gap in ecology and conservation. Biological Reviews 93:1032-1055.

Bodin Ö, Crona BI. 2009. The role of social networks in natural resource governance: what relational patterns make a difference? Global Environmental Change 19:366-374.

Boswell C, Smith K. 2017. Rethinking policy 'impact': four models of research-policy relations. Palgrave Communications 3. https://doi. org/10.1057/s41599-017-0042-z.

Burnett S, Illingworth L, Webster L. 2004. Knowledge auditing and mapping: a pragmatic approach. Knowledge and Process Management 11:25-37.

Buschke FT, Botts EA, Sinclair SP. 2019. Post-normal conservation science fills the space between research, policy, and implementation. Conservation Science and Practice 1:e73.

Butchart SHM, et al. 2010. Global biodiversity: indicators of recent declines. Science 328:1164-1168.

Cabin RJ. 2011. Intelligent tinkering: bridging the gap between science and practice. 2nd edition. Island Press, Washington, D.C.

Callon M. 1984. Some elements of a sociology of translation: domestication of the scallops and the fishermen of St Brieuc Bay. Sociological Review 32:196-233.

Carolan MS. 2006. Science, expertise, and the democratization of the decision-making process. Society \& Natural Resources 19:661-668.

Cash DW, Clark WC, Alcock F, Dickson NM, Eckley N, Guston DH, Jäger J, Mitchell RB. 2003. Knowledge systems for sustainable development. Proceedings of the National Academy of Sciences of the United States of America 100:8086-8091.

Cook CN, Mascia MB, Schwartz MW, Possingham HP, Fuller RA. 2013. Achieving conservation science that bridges the knowledge-action boundary. Conservation Biology 27:669-678.

Cvitanovic C, McDonald J, Hobday AJ. 2016. From science to action: principles for undertaking environmental research that enables knowledge exchange and evidence-based decision-making. Journal of Environmental Management 183:864-874.

Di Marco M, et al. 2017. Changing trends and persisting biases in three decades of conservation science. Global Ecology and Conservation 10:32-42.

Enengel B, Muhar A, Penker M, Freyer B, Drlik S, Ritter F. 2012. Coproduction of knowledge in transdisciplinary doctoral theses on landscape development-an analysis of actor roles and knowledge types in different research phases. Landscape and Urban Planning 105:106-117.

Fazey I, et al. 2013. Knowledge exchange: a review and research agenda for environmental management. Environmental Conservation 40:19-36.

Fleischman F, Briske DD. 2016. Professional ecological knowledge: an unrecognized knowledge domain within natural resource management. Ecology and Society 21. https://doi.org/10.5751/ES-08274210132 . 
Funtowicz SO, Ravetz JR. 1993. Science for the post-normal age. Futures 25:739-755.

Gibbons M. 2000. Mode 2 society and the emergence of contextsensitive science. Science and Public Policy 27:159-163.

Guerrero AM, Barnes M, Bodin Ö, Chadès I, Davis KJ, Iftekhar MS, Morgans C, Wilson KA. 2020. Key considerations and challenges in the application of social-network research for environmental decision making. Conservation Biology 34:733-742.

Guerrero AM, McAllister RRJ, Corcoran J, Wilson KA. 2013. Scale mismatches, conservation planning, and the value of social-network analyses. Conservation Biology 27:35-44.

Habel JC, Gossner MM, Meyer ST, Eggermont H, Lens L, Dengler J, Weisser WW. 2013. Mind the gaps when using science to address conservation concerns. Biodiversity and Conservation 22:24132427.

Hegger D, Lamers M, Van Zeijl-Rozema A, Dieperink C. 2012. Conceptualising joint knowledge production in regional climate change adaptation projects: success conditions and levers for action. Environmental Science \& Policy 18:52-65.

Hulme PE. 2014. Bridging the knowing-doing gap: know-who, knowwhat, know-why, know-how and know-when. Journal of Applied Ecology 51:1131-1136.

Jafari M, Akhavan P, Bourouni A, Roozbeh H. 2009. A framework for the selection of knowledge mapping techniques. Scholarly paper 2189714. Social Science Research Network, Rochester, New York. Available from https://papers.ssrn.com/abstract=2189714 (accessed January 2020).

Jasanoff S. 2009. The fifth branch: science advisers as policymakers. Harvard University Press, Cambridge, Massachusetts.

Jasanoff S. 2012. Science and public reason. Routledge.

Jetz W, McPherson JM, Guralnick RP. 2012. Integrating biodiversity distribution knowledge: toward a global map of life. Trends in Ecology \& Evolution 27:151-159.

Junker J, et al. 2012. Recent decline in suitable environmental conditions for African great apes. Diversity and Distributions 18:10771091.

Knight AT, et al. 2019. Improving conservation practice with principles and tools from systems thinking and evaluation. Sustainability Science 14:1531-1548.

Knight AT, Cowling RM, Rouget M, Balmford A, Lombard AT, Campbell BM. 2008. Knowing but not doing: selecting priority conservation areas and the research-implementation gap. Conservation Biology 22:610-617.

Lacey J, Howden M, Cvitanovic C, Colvin RM. 2018. Understanding and managing trust at the climate science-policy interface. Nature Climate Change 8:22-28.

Latour B. 1987. Science in action: how to follow scientists and engineers through society. Harvard University Press, Cambridge, Massachusetts.

Latour B. 2005. Reassembling the social - an introduction to actornetwork-theory. Oxford University Press, Oxford, United Kingdom.

Liebowitz J. 2005. Linking social network analysis with the analytic hierarchy process for knowledge mapping in organizations. Journal of Knowledge Management 9:76-86.

Liebowitz J, Rubenstein-Montano B, McCaw D, Buchwalter J, Browning C, Newman B, Rebeck K. 2000. The knowledge audit. Knowledge and Process Management 7:3-10.

Meine C, Soule M, Noss RF. 2006. "A mission-driven discipline": the growth of conservation biology. Conservation Biology 20:631-651.

Morgans CL, Guerrero AM, Ancrenaz M, Meijaard E, Wilson KA. 2017. Not more, but strategic collaboration needed to conserve Borneo's orangutan. Global Ecology and Conservation 11:236-246.

Morgan D, Mundry R, Sanz C, Ayina CE, Strindberg S, Lonsdorf E, Kühl HS. 2018. African apes coexisting with logging: Comparing chimpanzee (Pan troglodytes troglodytes) and gorilla (Gorilla gorilla gorilla) resource needs and responses to forestry activities. Biological Conservation 218:277-286.
Nguyen VM, Young N, Cooke SJ. 2017. A roadmap for knowledge exchange and mobilization research in conservation and natural resource management. Conservation Biology 31:789-798.

Nonaka I. 1994. A dynamic theory of organizational knowledge creation. Organization Science 5:14-37.

Pascual M, Miñana EP, Giacomello E. 2016. Integrating knowledge on biodiversity and ecosystem services: Mind-mapping and Bayesian Network modelling. Ecosystem Services 17:112-122.

Phelps C, Heidl R, Wadhwa A. 2012. Knowledge, networks, and knowledge networks: a review and research agenda. Journal of Management 38:1115-1166.

Plumptre A, Nixon S. 2016. New survey reveals dramatic decline of Grauer's gorilla. Oryx 50:203-203.

Porter TM. 1996. Trust in numbers: the pursuit of objectivity in science and public life. Princeton University Press, Princeton, New Jersey.

Pregernig M. 2014. Framings of science-policy interactions and their discursive and institutional effects: examples from conservation and environmental policy. Biodiversity and Conservation 23:36153639.

Prell C, Hubacek K, Reed M. 2009. Stakeholder analysis and social network analysis in natural resource management. Society \& Natural Resources 22:501-518.

Pusparini W, Batubara T, Surahmat F, Ardiantiono, Sugiharti T, Muslich M, Amama F, Marthy W, Andayani N. 2018. A pathway to recovery: the Critically Endangered Sumatran tiger Panthera tigris sumatrae in an 'in danger' UNESCO World Heritage Site. Oryx 52:25-34.

Raymond CM, Fazey I, Reed MS, Stringer LC, Robinson GM, Evely AC. 2010. Integrating local and scientific knowledge for environmental management. Journal of Environmental Management 91:17661777 .

Reed MS. 2008. Stakeholder participation for environmental management: a literature review. Biological Conservation 141:24172431.

Reed MS, et al. 2013. Knowledge management for land degradation monitoring and assessment: an analysis of contemporary thinking. Land Degradation \& Development 24:307-322.

Reed MS, Graves A, Dandy N, Posthumus H, Hubacek K, Morris J, Prell C, Quinn CH, Stringer LC. 2009. Who's in and why? A typology of stakeholder analysis methods for natural resource management. Journal of Environmental Management 90:1933-1949.

Roux D, Rogers K, Biggs H, Ashton P, Sergeant A. 2006. Bridging the science-management divide: moving from unidirectional knowledge transfer to knowledge interfacing and sharing. Ecology and Society 11. https://www.ecologyandsociety.org/vol11/iss1/art4/.

Scarano FR, Padgurschi MCG, Pires APF, Castro PFD, Farinaci JS, Bustamante M, Metzger JP, Ometto JP, Seixas CS, Joly CA. 2019. Increasing effectiveness of the science-policy interface in the socioecological arena in Brazil. Biological Conservation 240:108227.

Soberon JM, Sarukhan JK. 2009. A new mechanism for science-policy transfer and biodiversity governance? Environmental Conservation 36:265-267.

Sörlin S. 2012. Environmental humanities: why should biologists interested in the environment take the humanities seriously? BioScience 62:788-789.

Stevens CJ, Fraser I, Mitchley J, Thomas MB. 2007. Making ecological science policy-relevant: issues of scale and disciplinary integration. Landscape Ecology 22:799-809.

Tengö M, Hill R, Malmer P, Raymond CM, Spierenburg M, Danielsen F, Elmqvist T, Folke C. 2017. Weaving knowledge systems in IPBES, $\mathrm{CBD}$ and beyond-lessons learned for sustainability. Current Opinion in Environmental Sustainability 26-27:17-25.

Toomey AH, Knight AT, Barlow J. 2017. Navigating the space between research and implementation in conservation: researchimplementation spaces. Conservation Letters 10:619-625.

Vail EF III. 1999. Knowledge mapping: getting started with knowledge management. Information Systems Management 16:16-23. 
van Andel AC, Wich SA, Boesch C, Koh LP, Robbins MM, Kelly J, Kuehl HS. 2015. Locating chimpanzee nests and identifying fruiting trees with an unmanned aerial vehicle. American Journal of Primatology 77:1122-1134.

van Kerkhoff L, Lebel L. 2006. Linking knowledge and action for sustainable development. Annual Review of Environment and Resources 31:445-477.

Vimal R. 2017. Monitoring for conservation in African tropical national parks: an agenda towards policy-relevant science. Biological Conservation 214:127-135.

Vimal R, Gatiso T, Mathevet R. 2018a. Monitoring in tropical national parks: the power of knowledge. Conservation and Society 16:76.
Vimal R, Khalil-Lortie M, Gatiso T. 2018b. What does community participation in nature protection mean? The case of tropical national parks in Africa. Environmental Conservation 45: 333-341.

Voigt M, et al. 2018. Global demand for natural resources eliminated more than 100,000 Bornean Orangutans. Current Biology 28:761769.e5.

Wexler MN. 2001. The who, what and why of knowledge mapping. Journal of Knowledge Management 5:249-264.

Wood BA, Blair HT, Gray DI, Kemp PD, Kenyon PR, Morris ST, Sewell AM. 2014. Agricultural science in the wild: a social network analysis of farmer knowledge exchange. PLOS ONE 9:e105203. http://doi. org/10.1371/journal.pone.0105203. 